\title{
Erratum zu: HDX-MS in den Lebenswissenschaften
}

WIELAND STEINCHEN, UWE LINNE, GERT BANGE

LOEWE-ZENTRUM FÜR SYNTHETISCHE MIKROBIOLOGIE (SYNMIKRO) UND FACHBEREICH CHEMIE, UNIVERSITÄT MARBURG

DOI: $10.1007 / \mathrm{s} 12268-018-0880-2$

(C) Springer-Verlag 2017

Veröffentlicht: November 2017

(C) Springer-Verlag $\mathrm{GmbH}$

DOI: $10.1007 / \mathrm{s} 12268-017-0871-8$

- Bei der Produktion der bereits veröffentlichten Originalversion des Artikels ist ein Fehler in der Legende zu Abbildung 1 entstanden. Die Farbbezeichnungen bei Wasserstoff (blau) und Deuterium (rot) waren vertauscht. Anbei finden Sie die korrigierte Version.

Wir entschuldigen uns für den Fehler und für alle dadurch eventuell entstandenen Unannehmlichkeiten.

Die Online-Version des Originalartikels finden Sie unter der DOI: 10.1007/s12268-0170871-8.

Korrespondenzadresse:

Dr. Wieland Steinchen

LOEWE-Zentrum für Synthetische Mikrobiologie (SYNMIKRO)

Fachbereich Chemie

Philipps-Universität Marburg

Hans-Meerwein-Straße 4

D-35043 Marburg

Tel.: 06421-28-25516/-25526

wieland.steinchen@synmikro.uni-marburg.de
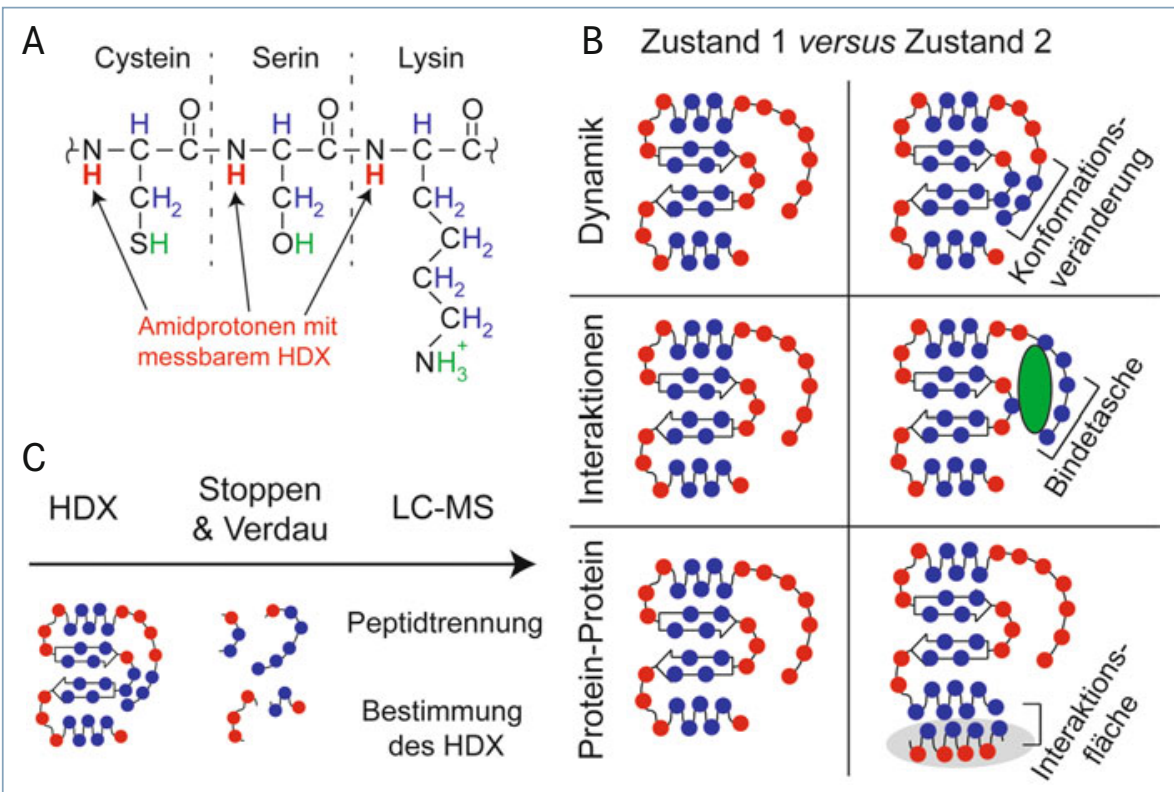

A Abb. 1: Grundlagen der HDX-MS. A, Die Lage Kohlenstoff- (blau) und Heteroatom-gebundener Protonen (grün) sowie Amidprotonen (rot) ist in einem Beispielpeptid dargestellt. B, HDX-MS ermöglicht die Analyse eines Proteins in verschiedenen Zuständen. Unterschiede im Gehalt von Wasserstoff (blau) und Deuterium (rot) erlauben Rückschlüsse auf Veränderungen der Konformation. C, vereinfachter Ablauf von HDX-MS-Messungen. Nach H/D-Austausch des Proteins in $\mathrm{D}_{2} \mathrm{O}$-haltigem Puffer wird die Reaktion gestoppt und das Protein proteolytisch verdaut. Die Peptide werden anschließend durch Flüssigchromatographie (LC) getrennt und ihr Deuteriumgehalt mittels Massenspektrometrie (MS) bestimmt. 